The University of Maine

DigitalCommons@UMaine

Publications

Senator George J. Mitchell Center for Sustainability

Solutions

$1-2017$

\title{
Managing small natural features: A synthesis of economic issues and emergent opportunities
}

Dana Bauer

Kathleen Bell

Erick Nelson

Aram J K Calhoun

University of Maine, Calhoun@maine.edu

Follow this and additional works at: https://digitalcommons.library.umaine.edu/ mitchellcenter_pubs

Part of the Environmental Policy Commons, and the Environmental Studies Commons

\section{Repository Citation}

Bauer, Dana; Bell, Kathleen; Nelson, Erick; and Calhoun, Aram J K, "Managing small natural features: A synthesis of economic issues and emergent opportunities" (2017). Publications. 49.

https://digitalcommons.library.umaine.edu/mitchellcenter_pubs/49

This Article is brought to you for free and open access by DigitalCommons@UMaine. It has been accepted for inclusion in Publications by an authorized administrator of DigitalCommons@UMaine. For more information, please contact um.library.technical.services@maine.edu. 


\section{Managing small natural features: A synthesis of economic issues and emergent opportunities}

Dana Marie Bauer a,,1, Kathleen P. Bellb,1, Erik J. Nelsonc,1, Aram J.K. Calhoun ${ }^{\mathrm{d}}$

${ }^{\text {a }}$ George Perkins Marsh Institute, Clark

University, Worcester, MA 01610, USA

${ }^{\mathrm{b}}$ School of Economics, University of Maine, Orono, ME 04469, USA

c Department of Economics, Bowdoin College, Brunswick, ME 04011, USA

${ }^{\mathrm{d}}$ Department of Wildlife, Fisheries, and Conservation Biology, University of Maine, Orono, ME 04469, USA

* Corresponding author at: George Perkins Marsh Institute, Clark University, Worcester, MA 01610, USA.

E-mail address: dbauer@clarku.edu (D.M. Bauer).

Senior authorship is shared among Bauer, Bell, and Nelson. 
ABSTRACT

Small natural features (SNFs), landscape elements that influence species persistence and ecological functioning on a much larger scale than one would expect from their size, can also offer a greater rate of return on conservation investment compared to that of larger natural features or more broad-based conservation. However, their size and perceived lack of significance also makes them more vulnerable to threats and destruction. We examine the management of SNFs and conservation of the associated ecosystem services they generate from an economics perspective. Using the economic concept of market failure, we identify three key themes that explain prevailing threats to SNFs and characterize impediments to and opportunities for SNF management: (1) the degree to which benefits derived from the feature spillover, beyond the feature itself (spatially and temporally); (2) the availability and quality of information about the feature and those who most directly influence its management; and (3) the existence and enforcement of property rights and legal standing of the feature. We argue that the efficacy of alternative SNF management approaches is highly case dependent and relies on four key components: (1) the specific ecosystem services of interest; (2) the amount of redundancy of the SNF on the landscape and the level of connectivity required by the SNF in order to provide ecosystem services; (3) the particular market failures that need correcting and their scope and extent; and (4) the magnitude and distribution of management costs.

\section{KEYWORDS:}

Biodiversity, Conservation, Ecosystem services, Land use, Small natural feature, Policy 


\section{INTRODUCTION}

A small natural feature (SNF) is a site with ecological importance that is disproportionate to its size; sometimes because it provides resources that limit key populations or processes that influence a much larger area; sometimes because it supports unusual diversity, abundance, or productivity (Hunter, this issue). Examples of SNFs include desert springs supporting endemic fish and other native species (Davis et al., this issue), large old trees supporting cavity-dependent mammals (Lindenmayer, this issue), caves supporting large colonies of bats (Medellin et al., this issue), and coral bommies supporting myriad marine life (Lundquist et al., this issue).

As argued throughout this special issue (see Hunter et al., this issue), SNFs have both ecological and socio-economic importance. Because SNFs are relatively small and often represent distinct ecosystems, they are surprisingly diverse and contribute to overall biodiversity (Lambertucci and Ruggiero, 2016; Davis et al., this issue; Fitzsimons and Michael, this issue). SNF-supported species often provide services to human enterprises such as agriculture, for example, by pollinating crops and controlling agricultural pests (Medellin et al., this issue; Poschlod and Braun-Richert, this issue). SNF-supported processes also generate human-valued services. For example, a modest riparian zone in a larger river valley can reduce the pollutant load entering the river and help moderate flooding peaks through the valley (Watson et al., 2016; González et al., this issue) and some temporary water bodies provide groundwater recharge (Acuña et al., this issue; Calhoun et al., this issue). SNFs also provide recreational values (e.g., spelunking and snorkeling [Huth and Morgan, 2011; Trujillo et al., 2016]), resource extraction (e.g., drinking water [Amondo, 2013]), and tourism and cultural amenities (e.g., aboriginal sites and cave art ([Rossi and 
Webb, 2007; Daniel et al., 2012]). While we can generally describe SNFs and the ecosystems services they support (see Table 1 and the SNF case studies in this issue), socio-economic aspects of SNF management and consequent impacts on the interactions among ecological and human systems remain poorly understood.

Because small natural features support ecosystem services of value disproportionate to their size, a focus on SNF management presents opportunities for cost-effective conservation, especially compared to larger natural features or more broad-based conservation efforts. However, the management of SNFs and the conservation of associated ecosystem services are proving to be complex. First, their small stature means their over-sized contribution to the landscape's provision of ecosystem services is often unrecognized. Second, most conservation practices and polices used today are designed for landscape-sized conservation and are mal-adapted for SNF-scale conservation. Third, as made clear by the feature-specific articles of this issue (e.g., Davis et al., this issue; Fitzsimons and Michael, this issue; Medellin et al., this issue), formal targeted protections of these landscape elements have thus far been limited, making the promise of cost-effective conservation from well-managed SNFs a non-trivial task. This synthesis is intended to complement the articles of this special issue and call attention to management issues and research needs.

In this paper, we examine the management of SNFs from an economics perspective. In particular, we use the economic concept of market failure to explain the human behavior behind prevailing threats to SNFs and to characterize impediments to and opportunities for SNF management. Market failure is the key concept used by economists and other policy scientists to inform environmental policy and natural resource management (Hackett, 2010; 
Sterner and Coria, 2013). Briefly, most goods and services such as apples, cell phones, and haircuts are exchanged through well-functioning markets. In contrast, goods and services provided by nature are not typically exchanged in markets because one or more conditions prevent their formation or undermine their functioning. Here, we explain the concept of market failure in more detail to lay the foundation for discussion of SNF challenges and management opportunities.

We also assess the efficacy of alternative SNF management approaches. We argue that efficacy is a function of: (1) the types of ecosystem services generated; (2) the amount of redundancy of the SNF on the landscape and the level of connectivity required by the SNF in order to provide ecosystem services; (3) the market failures that need correcting and their scope and extent; and (4) the magnitude and distribution of management costs. We consider the potential mismatch between traditionally used conservation approaches (e.g., large-scale reserves) and SNFs, and explore the usefulness of under-utilized approaches (e.g., tradable development rights, impact fees, and payments for ecosystem services). While we draw on an economic perspective, our arguments acknowledge and appreciate other social science perspectives (Ostrom et al., 2002; Dietz et al., 2003; Saunders et al., 2006; Schlüter et al., 2017) and their important contributions to environmental conservation (Berkes, 2007; Daniel et al., 2012; Hilbig et al., 2013). Although full consideration of these contributions is beyond the scope of this paper, we incorporate insights from these other fields into our synthesis. Further, by evaluating the need for and efficacy of distinct conservation approaches for SNFs, we strive to initiate new policy discussions and lines of scientific research, as well as foster collaboration among natural and social scientists (Saunders et al., 2006; Heberlein, 2012; Calhoun et al., 2014). 
MARKET FAILURES AND ISSUES IN SNF MANAGEMENT

The economic concept of market failure provides a useful means to examine the need for SNF management and to assess the performance of alternative conservation approaches. Economists identify several characteristics of well-functioning markets (Hackett, 2010; Sterner and Coria, 2013). Market failures occur when one or more of these characteristics are missing. Of particular importance to SNFs are situations in which third parties are impacted in a positive or negative manner despite being outside the producer-consumer transaction. For example, landowners who maintain or restore riparian zones or temporary water bodies to ensure the quality of their well water may incidentally contribute to the quality of neighboring well water (Trenholm et al., 2013; Acuña et al., this issue; Calhoun et al., this issue). However, because there is no formal mechanism through which the landowner can charge his neighbors a fee for improved water quality, he only engages in the level of restoration and ongoing maintenance that meets his private needs. It could be that neighbors would be willing to pay an amount for additional riparian zone restoration that would more than cover the landowner's additional restoration costs, making everyone better off. The foregone value that would accrue to neighbors from additional restoration measures is the extent of the market failure.

Applied to SNFs, three relevant themes emerge when comparing and contrasting market failures across different features: (1) the degree to which benefits derived from the feature spillover to third parties not involved in its management; (2) the availability of information about both the feature itself and the values held by the feature's landowner; and ( 3 ) the existence and enforcement of property rights and legal standing of the feature. Each is discussed below in more detail. Throughout these discussions, we use a simplified example 
of a SNF in a terrestrial setting with a single landowner that holds all property rights for ease of exposition, although we acknowledge that more complex ownership and property rights regimes exist.

Spatial spillovers of SNF-generated ecosystem services

The spatial mismatch between SNF management costs and benefits complicates their management. Many SNFs are relatively small and located on a single parcel of land with management costs incurred by an individual landowner. In contrast, most SNF-generated benefits reach well beyond parcel boundaries to other beneficiaries, an economic concept known as positive spatial externalities or spatial spillovers. In many instances, the landowner is unable to exclude others from receiving the ecosystem services provided and, thus, cannot demand payment for these benefits. While some beneficiaries might make voluntary contributions, others will free ride off the generosity of their neighbors and the landowner will not receive full compensation for services provided. Attempts by the landowner to capture full payment will likely be too cumbersome to implement, or may be impossible due to her inability to exclude others from receiving benefits.

To illustrate, consider a single large, old tree growing in a meadow. The tree is private in the sense that the owner of the meadow can do what she wants with the tree, including having it removed. However, her neighbors also benefit from the varied ecosystem services provided by the tree. Up to this point, the meadow owner has not removed the tree because the private value she has received from viewing the tree and the species that nest in its cavities has been greater than the additional cost created by cumbersomely mowing around the tree and raking its leaves. Recently, however, the meadow owner has become 
increasingly annoyed with cumbersome mowing and raking, and is considering having it removed; her private benefit of the tree has fallen below her private cost of maintaining it. Yet, from society's point of view, the tree's benefit stream is much greater than the meadow owner's private cost and social cost-benefit analysis argues for the tree's continued presence. Those that value the scenic view created by the single large, old tree soaring over the meadow can repeatedly indulge in the benefit it creates at no cost. Unfortunately, unless society provides an institution that allows the meadow owner to convert the tree's aggregate social value into adequate compensation, she is likely to ignore the societal cost-benefit analysis. Even if passersby wanted to pay for the tree's beauty, there would be no formal mechanism to do so. Further, any attempts by the meadow owner to exact a toll from passersby (e.g., by hiring someone to collect a fee) would likely cost her more than the money raised.

Similar examples occur for other SNFs (Table 2). For example, positive spatial spillovers occur when prairie potholes provide duck habitat that benefits hunters and when caves provide bat habitat that benefits farmers hundreds of miles away. SNF support of biodiversity and other non-use values (e.g., cultural values for sites not visited), where beneficiaries are numerous and widespread, is the extreme example of a positive spatial spillover.

Imperfect information

Information flows between buyers and sellers of goods and services are central to well-functioning markets. Management of SNFs and conservation of the services they provide is made difficult by a lack of information on the ecological processes that SNFs 
support and, in some instances, an asymmetry in information among key human actors (e.g., private landowners and government regulators). First, a lack of detailed information about SNF benefits, combined with their small stature, has led to perceptions of insignificance by landowners, regulators, policy makers, and the public (Acuña et al., this issue; Davis et al., this issue; Fitzsimons and Michael, this issue). Even scientists not directly involved in the study of a specific type of SNF may be misinformed of its associated ecosystem services. For example, vernal pools are not just small versions of permanent wetlands; they provide habitat for a different set of species and perform different ecological functions (Calhoun et al., this issue). Rocky outcrops are not lifeless geological formations, but supporters of biodiversity by regulating microclimate and providing cavities to escape predation (Michael et al., 2010; Fitzsimons and Michael, this issue). Widespread perceptions of insignificance can perpetuate the information problem over the long term as limited research, management, and outreach funds will go to natural features perceived to be more important.

Further, the locations of many SNFs are unknown to landowners and regulators given their small stature or temporary nature (e.g., temporary wetlands or streams) or that they are underwater or underground (e.g., caves or reefs). While recent advances in remote sensing techniques (Pettorelli et al., 2014; Jetz et al., 2016) and applications of citizen science and mobile technologies (Jansujwicz et al., 2013)offer great potential for locating SNFs, some of these technologies or approaches may be expensive to employ consistently over large areas.

Additionally, even if landowners are aware of SNFs on their property, they may not reveal this information to government officials. If the presence of a SNF could lead to restrictions 
of their future land use or management options, we can expect some landowners to hide it from regulators (Brook et al., 2003), or worse yet, destroy it before the regulator can become aware of its existence. This information asymmetry issue is similar to that in endangered species protection (Arguedas and van Soest, 2011) and is known as the "shoot, shovel, and shut up" phenomenon (Polasky and Doremus, 1998; Lewis and Nelson, 2014). As long as the cost of destruction and the probability of the regulator detecting the destruction are both low, which is likely to be true of many SNFs, destroying the SNF could be enticing. Information asymmetries between resource users and regulators of ecosystem services can also be an issue even if the SNF is on public land. Suppose a government gives a logging company a timber concession in a publicly owned forest. If the logging company comes across an old, large tree that the regulator does not know about, the company is likely to have little to no motivation to tell the regulator of its existence unless given an incentive to do so.

Even if significance is acknowledged and locations are known, there may still be a lack of information on the quality of the ecosystem services provided by individual SNFs. Classification systems are often used by research scientists and government regulators to differentiate among SNF quality (Harris, 1992; van Beynen, 2011). For example, the Maine (U.S.) vernal pool regulation distinguishes a subset of vernal pools as significant based on specific scientific criteria. Unfortunately, individual landowners may not fully understand these criteria and must either protect the pool not knowing its status (so, perhaps unnecessarily) or incur the cost of hiring a consultant to determine its status.

Finally, if the goal of SNF management is to maximize social welfare, or if the management mechanism involves payments to SNF landowners equal to their cost of SNF 
management, then the implementing government agency or non-profit organization will need to acquire information on landowner stewardship values and management costs, as well as accurately measure the services the SNFs provide, in order to offer an efficient payment. In most cases, finding all of this information is difficult, if not impossible.

III-defined or unenforced property rights, legal standing, and social status

A lack of clearly defined property rights over SNFs, whether the rights are individual, communal, or state, can undermine their management. Ill-defined or unenforced property rights can result in the overexploitation of SNFs because multiple people will exploit the resource and each person's incentive is to exploit what they can before others do. For example, if it is unclear who has the right to determine the fate of a coral bommie, an angler may race to harvest the valuable fish resources the bommie supports before his rival anglers do. Similarly, scuba divers and snorkelers may arrive in overabundance or during key breeding seasons, disturbing wildlife populations or damaging the reef itself. A lack of property rights means the individual angler or diver does not have to be worried about being punished for any action he takes. Alternatively, if the reef were owned or formally managed by an individual, small group, or the local village, decisions over the SNF could be more deliberate.

In some cases, property rights may be well established, but they might conflict with one another. For example, private rights to land use (e.g., farming or mining) often conflict with the emerging consensus in many cultures that the public has a right to a certain level of environmental quality, and the choice between a "polluter pays" or a "beneficiary pays" conservation approach will vary among societies, land use type, and ecosystem services 
provided (Wegner, 2016). In other cases, property rights might belong jointly to a large group or even an entire nation (e.g., consider the 200-mile exclusive economic zone in the marine realm), with potential for large and often prohibitive costs for coordination of management efforts and enforcement. For example, Witjira National Park in Australia was formed to protect over 60 mound springs, however the large number of visitors to the park and limited ranger presence resulted in many springs becoming degraded (Harris, 1992).

Many SNFs support ecosystem services with direct use values (Table 1) such as recreation (e.g., spelunking in caves), tourism (e.g., visiting hot springs), and resource extraction (e.g., collecting guano from caves, harvesting large, old trees) can attract an overabundance of users. Often, direct use value is created by physical contact with SNFs that can pose threats to the other ecosystem services they provide. For example, caves and rocky outcrops are particularly vulnerable to overuse, in part because their hard surfaces create a perception of permanence and users are unaware of the subtle impacts their presence makes on the physical structure and nearby wildlife (Moncrieff, 2000; Rossi and Webb, 2007). Some SNFs in this category have features that attract a specific use (e.g., cave art viewing, hot springs bathing) which then lead to more general uses (e.g., hiking, wildlife viewing) and potential abuses in the surrounding area. This is more likely to occur on public lands, but it can also occur on private lands.

Related to property rights is the issue of legal standing. The extent to which SNFs qualify for legal protection - for example, are small, temporary water bodies entitled the same level of protection as larger, permanent water bodies?-and the extent to which they are regarded as significant by scientists, government officials, and the public, influences the formation and functioning of human institutions. Arguably, the small size of SNFs may 
account for a lack of legal and social standing for many of the features examined in this special issue. Consider that the US Endangered Species Act provides protection for old growth forests, habitat for an endangered spotted owl, but not for individual old, large trees, and the US Clean Water Act protects rivers and lakes, but not all temporary wetlands or streams. In comparison, temporary streams in Australia are considered watercourses similar to larger, permanent streams, while the European Union is inconsistent in its treatment of temporary streams depending on the region (Acuña et al., 2014).

Further, interactions among legal and social standing introduce interesting dynamics within this management context. For example, if perceptions of SNF insignificance exist among private landowners, they may ignore regulatory limits on SNF use or destruction. Conversely, if perceptions of SNF significance exist among landowners, they may act as stewards even without formal regulations. For example, farmers in Costa Rica maintain remnant trees for personal enjoyment in addition to other more practical reasons like firewood and wind protection (Harvey and Haber, 1998) and two thirds of riparian landowners surveyed in Oregon (US) consider land stewardship a moral obligation (Rosenberg and Margerum, 2008). Similar dynamics may influence SNF support and research by scientists.

\section{APPROACHES FOR MANAGING SNFS}

To address market failures, societies can establish policies, programs, or institutions that align the interests of private landowners with social interests, provide or reveal missing information, or establish and enforce property rights. In some cases, this will involve governments regulating landowner behavior, forcing landowners to bear the management 
costs. In other cases, government agencies or non-profits offer financial or non-financial incentives to providers of valuable ecosystem services to facilitate provisioning of the socially efficient amount. In still other instances, defining and enforcing property rights or changing the legal standing of a resource can lead to better conservation outcomes. Generalizing management strategies by SNF type is not useful because SNF situations can vary dramatically. Rather, the choice of management approach may be primarily driven by the particular ecosystem service(s) of interest and the type and extent of market failures.

Managing SNF with positive spatial spillovers where the "polluters" pay

In situations where regulators or the public at large have decided public rights to environmental quality and ecosystem service provision overrule the private property rights of individual landowners, a variety of SNF management approaches have potential. In these "polluter pays" approaches, the cost burden of managing the SNF to provide the socially desired level of ecosystem services falls on the landowner. As we consider alternative approaches to manage spatial spillovers, we assume that property rights are well defined (i.e., ill-defined property rights are not the reason for market failure and are discussed in a later section), while non-excludable benefits that spill over parcel boundaries are the reasons for market failure. We begin our discussion with regulatory approaches and continue through to more market-based approaches.

Land use regulations limit the type and intensity of activities allowed on a parcel and typically establish a baseline of land-use intensity across a relatively large region. Historically, these baselines have been set too high for the sustainable provisioning and 
socially desired level of SNF ecosystem services (Acuña et al., this issue; Calhoun et al., this issue; Davis et al., this issue). There are a number of advantages to untargeted land-use regulations. All landowners are treated the same, so there is no need to negotiate specific contracts. Changes to existing regulations can occur without consulting all affected landowners. Further, the regulator does not need to know the exact value of the ecosystem services provided or landowner opportunity costs to devise policy, and no coordination of activities among landowners is required (i.e., there are minimal administrative costs). Finally, land-use regulations may also be perceived as equitable as all landowners share the burden of conservation. However, because SNFs and their ecosystem service benefits are not evenly distributed across the landscape, a typical landscape-wide land-use regulation might not target a SNF's conservation problem very well. For commonly occurring SNFs, such as prairie potholes in North America and mound springs in southern Australia, extremely large opportunity costs could make the policy politically infeasible. Treating all SNFs the same may be perceived as equitable, but could be highly inefficient (i.e., not cost-effective) if the provisioning of ecosystem services is variable among individual occurrences. In summary, untargeted land-use regulations, while administratively straightforward, could create large costs for little SNF-generated benefit. Although there are several ways to target land-use regulations while reducing overall opportunity costs (e.g., Bauer et al., 2010; Freeman and Bell, 2011), increases in regulatory flexibility to address ecological heterogeneity often create higher administrative costs. That is, a tradeoff exists between the opportunity costs to landowners and the administrative costs to the regulator, and it may be unclear which approach minimizes the total cost burden to society.

Transferable development rights (TDR) programs set an overall limit on the amount of 
development (e.g., number of housing units) that can take place and distribute these rights (i.e., development permits) among current landowners (Chiodelli and Moroni, 2016). There are several advantages to TDRs over untargeted land-use regulation. Landowners can use the permit to develop their own parcel or sell the permit to another landowner, such that landowners are at least partially compensated for not developing. Therefore, compared to untargeted land-use regulations, they can minimize the amount that the "polluters pay". When TDRs are combined with additional land-use restrictions (e.g., designated open space areas), high quality SNFs can be spatially targeted for lower intensity use, although the information costs associated with identifying these SNFs could be large. There are also some disadvantages to TDRs. By restricting overall development in a community, TDRs can generate high opportunity costs. Alternatively, allowing the same amount of housing but on less land can create housing patterns that are less attractive to home buyers (Kopits et al., 2007). Transaction costs associated with bringing buyers and sellers together in a TDR market, as well as ongoing monitoring and enforcement costs, could be high. Finally, distributing development rights evenly among current landowners might be socially inefficient if some of the landowners receiving a permit were not going to develop anyway, thereby being compensated for conservation that would have occurred without the TDR program.

Impact fees are payments from landowners for permitted development or other intensive land uses (e.g., a tax on fertilizer or pesticide use) that results in ecological damages. The regulator could set a simple one-size fits all fee, thereby lowering administration costs; however, this could result in fees that severely under or overvalue benefits and lead to increased litigation. Instead, the regulator could attempt to set the fee or tax equal to the 
value of the ecosystem services lost via the development or land management activity. Such a system would ensure that landowners pay for their exact damage, however, the cost of determining which ecosystem services will be damaged by an activity and the controversy and uncertainty of measuring the level of damage in monetary terms are likely to be quite high (Ruckelshaus et al., 2015). This is particularly true in cases where SNF location is unknown to regulators or where linkages to ecosystem service provisioning remain highly unstudied. Thus, use of impact fees may be best when there are no additional information costs.

Managing SNF with positive spatial spillovers where the "beneficiaries" pay

In situations where the private property rights of individual landowners are favored over society's rights to ecosystem service provisioning, other management approaches may be more appropriate. In these "beneficiary pays" approaches, the cost burden of managing the SNF to provide the socially desired level of ecosystem services falls on those who receive value from the ecosystem services and are often borne by government agencies or non-profits. Again, we assume for simplicity of discourse that property rights are well defined. We begin our discussion of such approaches by summarizing large-scale acquisition approaches and continue through to more flexible and individualized approaches.

The extreme and arguably most common approach to conservation for which beneficiaries pay involves the outright purchase of land (i.e., fee simple acquisition) by a government agency or non-profit organization (e.g., a land trust), that often permanently protects the land in a natural state. From an ecological perspective, this approach can be 
highly successful. However, this approach can also be extremely expensive and is likely inefficient for the management of SNFs, particularly small and widely distributed SNFs such as temporary wetlands, rocky outcrops, and single large trees that may be able to co-exist on working lands (Calhoun et al., this issue; Fitzsimons and Michael, this issue; Lindenmayer, this issue).

Conservation easements separate use rights from the land itself (Rissman et al., 2007). Payments are typically made to landowners for the purchase of development rights (PDRs), but may also target water, mining, or grazing rights. In other words, the purchaser of development or other use rights can target specific SNF-generated ecosystem services in specific locations. The landowner retains ownership and may continue to use the land in other less-harmful ways depending on which use rights remain intact. Conservation easements are less costly than outright purchase, but may still be expensive depending on the use rights that are given up. Easements do have their issues, however. Determining the value of easements can be difficult and large transactions costs may be associated with negotiating individual contracts. In addition, because many agreements are termed in perpetuity, ongoing monitoring and enforcement costs can be quite high (Fitzsimons and Carr, 2014).

Targeted payments for ecosystem services (PES) and other subsidies can be made to landowners as incentives to: (1) engage in some activity or group of activities that maintain, restore, or improve the provision of one or more ecosystem services (e.g., creating vegetative buffer strips, installing fencing, or delaying mowing); (2) reduce the intensity of active land uses (e.g., grazing fewer cattle or building fewer homes); or (3) cease productive land use altogether. Payments can be monetary or in-kind and can come from government 
agencies, non-profits, or the direct beneficiaries (Engel et al., 2008; Engel, 2016). Recall the meadow owner with her large, old tree; she was bearing the cost burden of providing a good that society valued much more than she did. Rather than forcing her to bear this burden via a policy that prohibits private landowners from removing old trees, beneficiaries (e.g., the local community) could pay her for the service flow her tree provides. However, the administrative costs of PES schemes can be quite high, and it can be extremely difficult to select the best participants from a group of applicants (Sorice et al., 2011, 2012). For example, landowners are more knowledgeable of opportunity costs than regulators and, therefore, can extract payments that are much higher than their minimum willingness to accept (Lennox and Armsworth, 2013; Polasky et al., 2014). In addition, the offering of payments may change the framing of environmental behavior and weaken the landowner's sense of a moral obligation (Thorgersen, 1996). In both cases, less conservation is accomplished than is possible because recipients would have accepted smaller payments leaving funds for extra conservation elsewhere. Additionally, if private landowners know that the key to conserving landscape-wide ecosystem services hinges on SNF conservation on their land, then they may be able to bargain for exorbitant conservation payments (Polasky and Doremus, 1998; Arguedas and van Soest, 2011). Further, to maximize gains in social welfare, PES schemes have to set payments equal to the value of benefits procured, but determining their values can be challenging (Pattanayak et al., 2010). For example, how much value does the large tree in the middle of the meadow actually provide to society?

Finally, while individual landowners will generally account for personal stewardship values in their private decision-making, it may be possible to motivate additional stewardship through non-monetary rewards such as public acknowledgement of specific 
stewardship efforts or through public admonishment of a lack of stewardship (Harvey and Haber, 1998; Ryan et al., 2003; Rosenberg and Margerum, 2008; Pasquini et al., 2010).

Managing SNF in situations with imperfect or asymmetric information

A lack of information can be an impediment to SNF management. Subsidies that offer education opportunities to landowners and regulators about the ecosystem services provided by SNFs can help to change perceptions of insignificance that leads to better management. Subsidies in the form of research funds can help to develop and promote new remote sensing technologies (Pettorelli et al., 2014; Jetz et al., 2016). Public education can foster citizen science programs to help locate SNFs (Jansujwicz et al., 2013). In the case of asymmetric information, where the landowner knows the location of a SNF, the use of auctions rather than direct payments for ecosystem services is one way to get landowners to reveal their private values (Stoneham et al., 2003; Jack et al., 2009). In other situations, motivating stewardship values may be enough to gain landowner participation in conservation programs.

Managing SNF in situations with imperfect property rights

While situations of a complete lack of property rights are rare, situations where ownership rights are established but use rights are ill-defined, unenforced, or conflict with each other occur frequently on public lands and in the marine environment. For common resources like these, ill-defined use rights can induce problems of over-exploitation. Man- 
agement for direct use values often focuses on limiting the type, timing, or amount of use at the location of the SNF itself.

Permits and licenses are regulatory mechanisms that allow holders to use a particular SNF in a proscribed way. In this manner, governments can use permits as a mechanism to establish specific property rights. A government agency limits or regulates the number and type of permits issued, which may have a temporal (e.g., seasonal, day/night) or tiered-use (e.g., unrestricted access/restricted access requiring a permit/no access) configuration. Permits may be given away for free, sold for a fee, or may be auctioned to the highest bidder, with generated revenues used to cover infrastructure, administrative, monitoring, and enforcement costs.

User fees are market-based mechanisms that establish prices for public goods and services. The idea is that by charging a fee, direct use can be reduced. Prices can be implemented using different types of market segmentation (e.g., higher prices during peak use times or higher prices for more intensive uses) with the idea that higher prices will lower demand for SNF use. For many ecosystem goods and services, determining the socially efficient price can be a challenge. In those cases, survey research and other non-market valuation techniques can be used, for example, to determine park and cave entrance fees (Tapsuwan et al., 2010). Again, revenues can be used to cover a variety of management costs.

As an alternative to formal property rights regimes, local communities or user groups (e.g., hunting associations or spelunker societies) can establish informal institutions, such as community-based conservation plans, and social norms that facilitate cooperative and sustainable management that benefits the entire community (Ostrom et al., 2002; Dietz et 
al., 2003; Berkes, 2007). These types of arrangements benefit from local knowledge and social peer structures.

SNF management synthesis

We expect the efficacy of alternative SNF management approaches to be highly case dependent and influenced by four key components: (1) the specific ecosystem services of interest; (2) the amount of redundancy of the SNF on the landscape and the level of connectivity required by the SNF in order to provide ecosystem services; (3) the particular market failures that need correcting and their scope and extent; and (4) the magnitude and distribution of management costs. Below, we consider each of these components in an effort to provide insights for practitioners, regulators, and policy makers.

Most broad categories of SNFs provide a wide variety of ecosystem services (Table 1); however, an individual SNF occurrence may be most valued for its provision of one kind of service. One cave may contain prehistoric cave art and be a popular tourist attraction, while another may be a hotspot for spelunkers, and still another may be a major roosting site for hibernating bats. Identification of the specific ecosystem service of interest is important because it determines: the spatial extent of the landscape/seascape that managers or regulators have to worry about (i.e., the conservation zone), the uses of that landscape that are impairing the ability of the SNF to provide its services, and how many parties need to be involved in the feature's conservation. Some ecosystem services provided by SNFs (like flood control) require coordinated activity across large landscapes and other ecosystem services can be affected by landscape-wide disturbances like pollution (e.g., vernal pools). 
Conservation of these ecosystem services will require many people to be involved in a conservation plan. In other cases, such as protecting roosting habitat for bats in caves, conservation activities may be focused on a smaller geographic area and involve few parties. When the conservation zone is large, conservation costs will generally be higher. Coordinating intervention will also be more difficult. If the number of landowners needed for conservation success is low, then market or incentive-based approaches (e.g., land purchases, easements, and payments for ecosystem services) are simpler. If many landowners need to be involved, then simple and crude approaches (e.g., land-use regulations, education) will often work better.

The level of redundancy of the SNF on the landscape and the level of connectivity required by the SNF in order to provide ecosystem services influence the appropriate conservation approach as well. For example, consider a series of caves in an area that all provide roosting habitat for bats. If each cave is unremarkable except for their habitat provision, then the destruction of some of the caves in the series may not appreciably affect the habitat service provided by the cave system. However, if one of the caves contains prehistoric cave art, while another is a hotspot for spelunkers, then each cave in the system has to be conserved or the provision of one or more ecosystem services will be lost. The flexibility of conservation strategies decreases as feature redundancy and connectivity requirements increase.

The types and extent of market failures associated with SNFs greatly influence the efficacy of alternative conservation approaches. A complete understanding of the ecological processes and associated ecosystem services is lacking to some degree for all SNFs (Hunter et al., this issue). This lack of information favors the use of crude and simple approaches 
such as untargeted land-use regulations or outright purchase, which are quite expensive, and perhaps explains the limited formal protections in place to conserve SNFs. Looking ahead, research and education that improve understanding of the linkages between SNFS and the ecosystem services they provide will broaden the feasibility and efficacy of more complicated approaches and address information problems including the "perception of insignificance" challenge. Managing to address ill-defined or unenforced property rights may be key for some SNFs, because without someone or some group with authority to make decisions and establish legal protections, it will be impossible to take steps towards formal management approaches. Given the likelihood of multiple types of market failures, strategies that rely on multiple approaches (polluter pays and beneficiaries pay; market and non-market based approaches; education; property rights) may prove most successful (Kinzig et al., 2011).

The magnitude and distribution of management costs also affect the efficacy of management approaches. Relevant costs include opportunity costs (i.e., foregone use benefits), management (administrative, monitoring, enforcement) costs, transaction (information, contracting, coordination) costs, and, in some cases, acquisition costs (Naidoo et al., 2006). Large-scale reserves are not likely to be cost-effective for managing the majority of SNFs due to the high costs associated with purchasing land outright. In comparison, economic incentives that reduce land-use intensity rather than eliminating all land uses, cost less and are beginning to show promise (e.g., see Perkins et al., 2011; Robertson et al., 2014). These lower costs are much more likely to fall within organizations' conservation budgets than larger landscape level projects.

Community attitudes towards conservation can influence the dominant property rights 
regime (i.e., "polluter pays" versus "beneficiary pays") which ultimately determines who incurs the management cost burden. Sharing the cost burden among landowners and the rest of society may result in higher total costs, but may provide more equitable (and perhaps more politically feasible) alternatives. However, there are many factors that influence conservation behavior including how an individual identifies socially (e.g., as a rancher or as an environmentalist) and the existence of multiple identities can lead to social conflict (Saunders et al., 2006). Social norms guide behavior, but changing social norms requires motivation in addition to education (Schultz, 2011). Understanding and capitalizing on patterns in human attitudes and behaviors towards SNFs, as well as the structure and nature of human policies and institutions regarding SNFs, affords tremendous opportunities for creating multiple pockets of cost-effective conservation across the larger landscape.

\section{SUMMARY}

In this paper, we examined the management of small natural features (SNFs) and conservation of the associated ecosystem services they generate from an economics perspective. Using the economic concept of market failure, we identified three key themes that explain prevailing threats to SNFs and characterize impediments to and opportunities for SNF management: (1) the degree to which benefits derived from the feature spillover to third parties not involved in its management, creating a mismatch between those who incur the costs of management and those who benefit; (2) the availability of information about the location and quality of the features, and the values they provide to the feature's landowner and society at large; and (3) the lack of existence and enforcement of well-defined ownership and use rights, and legal standing of the feature. While these types of market 
failures are not uncommon in biodiversity and ecosystem service conservation, SNFs' small stature, perceived insignificance, and unexpected large-scale spatial benefits increase the likelihood of SNF conservation failure.

After reviewing several conservation approaches, we noted that the efficacy of alternative SNF management approaches is highly case dependent and relies on four key components: (1) the specific ecosystem services of interest; (2) the amount of redundancy of the SNF on the landscape and the level of connectivity required by the SNF in order to provide ecosystem services; (3) the particular market failures that need correcting, and their scope and extent; and (4) the magnitude and distribution of management costs. The combination of these components for a specific SNF determines the most effective conservation mechanism(s).

These insights provide input to an initial roadmap for future conservation strategies (Hunter et al., this issue) and represent a first step in facilitating collaborations among natural and social scientists. Information, laws, institutions, programs, and technology designed to overcome these issues can seize opportunities for cost-effective SNF conservation. Research and education that improve our understanding of the linkages between SNFs and the ecosystem services they provide offers critical support of these efforts. Similarly, new remote sensing and mobile technologies and applications of citizen science offer tremendous potential. Finally, close collaborations among natural and social scientists (Saunders et al., 2006; Heberlein, 2012) will continue to expand our understanding of human and natural systems and the possibilities for SNF conservation. 


\section{ACKNOWLEDGEMENTS}

Funding was provided by the US National Science Foundation Coupled Natural Human Systems program (NSF/CNH 1313627). The authors thank Jessica Balukas and Abigail Kaminski for excellent research assistance, Malcolm Hunter for useful discussion, and two anonymous reviewers for thoughtful suggestions. 


\section{FIGURES}

Table 1

Ecosystem services provided by small natural features.

\begin{tabular}{|c|c|c|c|}
\hline Small natural feature & $\begin{array}{l}\text { Direct use values } \\
\text { (recreation, tourism, resource } \\
\text { extraction, research/education) }\end{array}$ & $\begin{array}{l}\text { Indirect use values } \\
\text { (regulating/supporting ecosystem services) }\end{array}$ & $\begin{array}{l}\text { Non-use values } \\
\text { (biodiversity) }\end{array}$ \\
\hline Caves & $\begin{array}{l}\text { - Caving } \\
\text { - Show caves, cave art } \\
\text { - Access to groundwater } \\
\text { - Guano extraction } \\
\text { - Sacred sites/temples }\end{array}$ & $\begin{array}{l}\text { - Support beneficial species (bats that provide } \\
\text { pollination, pest control, and nutrient cycling) } \\
\text { - Genetic materials and medicines }\end{array}$ & - Endemic species, some species at risk \\
\hline Rocky outcrops & $\begin{array}{l}\text { - Rock climbing } \\
\text { - Rock art, scenic vistas } \\
\text { - Shelter for livestock } \\
\text { - Rock, reptile extraction } \\
\text { - Sacred sites/temples }\end{array}$ & $\begin{array}{l}\text { - Support beneficial species (top predators } \\
\text { and pollinators) }\end{array}$ & $\begin{array}{l}\text { Rare species, endemic fauna, specialized flora } \\
\text { (adapted to extreme temperatures) }\end{array}$ \\
\hline Springs & $\begin{array}{l}\text { - Swimming, "bathing" } \\
\text { - Scenic vistas }\end{array}$ & - Water for livestock & - Endemic species \\
\hline Temporary wetlands & $\begin{array}{l}\text { - Wildlife viewing } \\
\text { - Duck hunting }\end{array}$ & $\begin{array}{l}\text { - Flood mitigation } \\
\text { - Groundwater recharge } \\
\text { - Pollution absorption, sediment retention } \\
\text { - Nutrient cycling - nitrogen } \\
\text { - Carbon sequestration } \\
\text { - Aquatic stepping stones, duck habitat }\end{array}$ & $\begin{array}{l}\text { - Some species at risk, specialized invertebrates } \\
\text { and amphibians }\end{array}$ \\
\hline Temporary streams & - Wildlife viewing & $\begin{array}{l}\text { - Flood mitigation } \\
\text { - Groundwater recharge } \\
\text { - Stream flow connectivity }\end{array}$ & - Connectivity, corridors \\
\hline Riparian zones & $\begin{array}{l}\text { - Scenic walkways } \\
\text { - Fishing }\end{array}$ & $\begin{array}{l}\text { - Flood mitigation } \\
\text { - Groundwater recharge } \\
\text { - Pollution absorption, nutrient retention } \\
\text { - Local climate regulation } \\
\text { - Carbon sequestration } \\
\text { - Supports beneficial species (fish stocks) }\end{array}$ & $\begin{array}{l}\text { - Microclimate } \\
\text { - Corridors }\end{array}$ \\
\hline Large old trees & $\begin{array}{l}\text { - Scenic feature } \\
\text { - Special sites } \\
\text { - Shade }\end{array}$ & $\begin{array}{l}\text { - Support beneficial species (pollination, seed } \\
\text { dispersal, pest control) in agroecosystems } \\
\text { - Carbon sequestration } \\
\text { - Water regulation }\end{array}$ & $\begin{array}{l}\text { - Rare and endangered species } \\
\text { - Stepping stones } \\
\text { - Microclimate }\end{array}$ \\
\hline Remnant forest & & $\begin{array}{l}\text { - Support beneficial species (pollination, seed } \\
\text { dispersal, pest control) in agroecosystems }\end{array}$ & \\
\hline Coral Bommies & $\begin{array}{l}\text { - Snorkeling, scuba diving, wildlife } \\
\text { viewing } \\
\text { - Fishing }\end{array}$ & - Supports beneficial species (fish stocks) & $\begin{array}{l}\text { - Endemic species } \\
\text { - Stepping stones }\end{array}$ \\
\hline
\end{tabular}


Table 2

Examples of management impediments by small natural feature.

\begin{tabular}{|c|c|c|c|}
\hline Small Natural Feature & Positive spatial spillovers & Imperfect or asymmetric information & $\begin{array}{l}\text { Non-existent or Ill-defined property rights or } \\
\text { legal standing }\end{array}$ \\
\hline Caves & $\begin{array}{l}\text { Many support bats that provide pest control } \\
\text { services on distant farms }\end{array}$ & $\begin{array}{l}\text { Location may be unknown because they are } \\
\text { underground }\end{array}$ & $\begin{array}{l}\text { May be difficult to keep out spelunkers or guano } \\
\text { harvesters }\end{array}$ \\
\hline Rocky outcrops & $\begin{array}{l}\text { Scenic vistas; support birds which provide } \\
\text { distant ecological functions }\end{array}$ & $\begin{array}{l}\text { Lack of knowledge surrounding services } \\
\text { ("it's just a rock") }\end{array}$ & Open access within parks may result in overuse \\
\hline Springs & $\begin{array}{l}\text { Connections to underground aquifers; support } \\
\text { mobile species }\end{array}$ & $\begin{array}{l}\text { Landowner values may be unknown to } \\
\text { regulators }\end{array}$ & Open access within some parks \\
\hline Temporary wetlands & $\begin{array}{l}\text { Groundwater recharge may extend to } \\
\text { neighboring parcels }\end{array}$ & $\begin{array}{l}\text { Small size and seasonality may prevent } \\
\text { knowing where they are }\end{array}$ & $\begin{array}{l}\text { Legal standing may be in question - not the } \\
\text { same as large wetlands }\end{array}$ \\
\hline Temporary streams & $\begin{array}{l}\text { Provide seasonal connectivity to neighboring } \\
\text { parcels/waterways }\end{array}$ & $\begin{array}{l}\text { Small size and seasonality may prevent } \\
\text { knowing where they are }\end{array}$ & $\begin{array}{l}\text { Legal standing may be in question - not the } \\
\text { same as large streams }\end{array}$ \\
\hline Riparian zones & $\begin{array}{l}\text { Downstream water quality benefits; habitat } \\
\text { for harvested species }\end{array}$ & $\begin{array}{l}\text { Landowner value for vegetative buffers } \\
\text { unknown to regulators }\end{array}$ & $\begin{array}{l}\text { "Ownership" of intermediary zone may be } \\
\text { uncertain or contentious }\end{array}$ \\
\hline Large Old trees & $\begin{array}{l}\text { Cultural amenities and scenic values to } \\
\text { neighbors }\end{array}$ & $\begin{array}{l}\text { Location may be unknown to regulators, } \\
\text { but known to harvesters }\end{array}$ & May be common pool resource \\
\hline Remnant forest & $\begin{array}{l}\text { Support wild pollinators and natural enemies } \\
\text { that benefit agriculture }\end{array}$ & Values to farmers unknown by regulators & May be common pool resource \\
\hline Coral bommies & Support nearby fishing and diving & $\begin{array}{l}\text { Locations may be unknown because they } \\
\text { are underwater }\end{array}$ & $\begin{array}{l}\text { Open access within national boundaries; } \\
\text { enforcement challenges }\end{array}$ \\
\hline
\end{tabular}




\section{REFERENCES}

Acuña, V., Hunter, M., Ruhí, A., 2017. Managing temporary waterways as unique rather than second-class ecosystems. Biol. Conserv. this issue.

Acuña, V., Datry, T., Marshall, J., Barceló, D., Dahm, C.N., Ginebreda, A., McGregor, G., Sabater, S., Tockner, K., Palmer, M.A., 2014. Why should we care about temporary waterways? Science 343 (6175), 1080-1081.

Amondo, E.I., 2013. Benefits of Spring Protection and Willingness to Pay for Improved Water Supply in Emuhaya District (Doctoral dissertation, University of Nairobi).

Arguedas, C., van Soest, D.P., 2011. Optimal conservation programs, asymmetric information and the role of fixed costs. Environ. Resour. Econ. 50, 305-323.

Bauer, D.M., Paton, P.W., Swallow, S.K., 2010. Are wetland regulations cost effective for species protection? A case study of amphibian metapopulations. Ecol. Appl. 20, 798815.

Berkes, F., 2007. Community-based conservation in a globalized world. Proc. Natl. Acad. Sci. 104 (39), 15188-15193.

Brook, A., Zint, M., De Young, R., 2003. Landowners' responses to an Endangered Species Act listing and implications for encouraging conservation. Conserv. Biol. 17, 16381649.

Calhoun, A.J.K., Mushet, D.M., Bell, K.P., Boix, D., Fitzsimons, J.A., Isselin-Nondedeu, F., 2017. Temporary wetlands: challenges and solutions to conserving a 'disappearing' ecosystem. Biol. Conserv. this issue.

Calhoun, A., Jansuwicz, J., Bell, K., Hunter Jr., M.L., 2014. Improving management of small natural features on private lands by negotiating the science-policy boundary of Maine vernal pools. Proc. Natl. Acad. Sci. U.S.A. 111, 11002-11006.

Chiodelli, F., Moroni, S., 2016. Zoning-integrative and zoning-alternative transferable development rights: compensation, equity, efficiency. Land Use Policy 52, 422-429.

Daniel, T.C., Muhar, A., Arnberger, A., Aznar, O., Boyd, J.W., Chan, K.M.A., Costanza, R., Elmqvist, T., Flint, C.G., Gobster, P.H., Grêt-Regamey, A., Lave, R., Muhar, S., Penker, M., Ribe, R.G., Schauppenlehner, T., Sikor, T., Soloviy, I., Spierenburg, M., Taczanowska, K., Tam, J., von der Dunk, A., 2012. Contributions of cultural services to the ecosystem services agenda. Proc. Natl. Acad. Sci. 109 (23), 8812-8819.

Davis, J.A., Kerezsy, A., Nicol, S., 2017. Springs: conserving perennial water critical in arid landscapes. Biol. Conserv. this issue. 
Dietz, T., Ostrom, E., Stern, P.C., 2003. The struggle to govern the commons. Science 302 (5652), 1907-1912.

Engel, S., Pagiola, S., Wunder, S., 2008. Designing payments for environmental services in theory and practice: an overview of the issues. Ecol. Econ. 65, 663-674.

Engel, S., 2016. The devil in the detail: a practical guide on designing payments for environmental services. Int. Rev. Environ. Resour. Econ. 9, 131-177.

Fitzsimons, J.A., Michael, D.R., 2017. Rocky outcrops: a hard road in the conservation of critical habitats. Biol. Conserv. this issue.

Fitzsimons, J.A., Carr, C.B., 2014. Conservation covenants on private land: issues with measuring and achieving biodiversity outcomes in Australia. Environ. Manag. 54, 606616.

Freeman, R.C., Bell, K.P., 2011. Conservation versus cluster subdivisions and implications for habitat connectivity. Landsc. Urban Plan. 101, 30-42.

González, E., Felipe-Lucia, M., Bourgeois, B., Boz, B., Nilsson, C., Palmer, G., Sher, A.A., 2017. Current management challenges and key measures to conserve riparian zones. Biol. Conserv. this issue.

Hackett, S.C., 2010. Environmental and Natural Resources Economics: Theory, Policy, and the Sustainable Society (ME Sharpe).

Harvey, C.A., Haber, W.A., 1998. Remnant trees and the conservation of biodiversity in Costa Rican pastures. Agrofor. Syst. 44, 37-68.

Harris, C.R., 1992. Mound springs: south Australian conservation initiatives. Rangel. J. 14 (2), 157-173.

Heberlein, T.A., 2012. Navigating environmental attitudes. Conserv. Biol. 26 (4), 583-585.

Hilbig, B.E., Zettler, I., Moshagen, M., Heydasch, T., 2013. Tracing the path from personality-via cooperativeness-to conservation.Eur.J.Personal. 27 (4), 319-327.

Hunter, M.L., 2017. Conserving small natural features with large ecological roles: an introduction and definition. Biol. Conserv. this issue.

Hunter, M.L., Acuña, V., Bauer, D.M., Bell, K.P., Calhoun, A.J.K., Felipe-Lucia, M.R., Fitzsimons, J.A., González, E., Kinnison, M., Lindenmayer, D., Lundquist, C.J., Medellin,R.A., Nelson,E.J., Poschlod,P., 2017. Conserving small natural features with large ecological roles: a synthetic overview. Biol. Conserv. this issue. 
Huth, W.L., Morgan, O.A., 2011. Measuring the willingness to pay for cave diving. Mar. Resour. Econ. 26, 151-166.

Jack, B.K., Leimona, B., Ferraro, P.J., 2009. A revealed preference approach to estimating supply curves for ecosystem services: use of auctions to set payments for soil erosion control in Indonesia. Conserv. Biol. 23, 359-367.

Jansujwicz, J.S., Calhoun, A.J.K., Lilieholm, R., 2013. The Maine vernal pool mapping and assessment program: engaging municipal officials and private landowners in community-based citizen science. Environ. Manag. 52, 1369-1385.

Jetz, W., Cavender-Bares, J., Pavlick, R., Schimel, D., Davis, F.W., Asner, G.P., Guralnick, R., Kattge, J., Latimer, A.M., Moorcroft, P., Schaepman, M.E., 2016. Monitoring plant functional diversity from space. Nat. Plants 2, 16024.

Kinzig, A.P., Perrings, C., Chapin, F.S., Polasky, S., Smith, V.K., Tilman, D., Turner, B.L., 2011. Paying for ecosystem services-promise and peril. Science 334, 603-604.

Kopits, E., McConnell, V., Walls, M., 2007. The trade-off between private lots and public open space in subdivisions at the urban-rural fringe. Am. J. Agric. Econ. 89 (5), 11911197.

Lambertucci, S.A., Ruggiero, A., 2016. Cliff outcrops as condor communal roosts are local hotspots of occupancy and intense use by other bird species. Biol. Conserv. 200, 816.

Lennox, G.D., Armsworth, P.R., 2013. The ability of landowners and their cooperatives to leverage payments greater than opportunity costs from conservation contracts. Conserv. Biol. 27, 625-634.

Lewis, D.J., Nelson, E.J., 2014. The economics of wildlife conservation. Chapter 7. In: Duke, J.M., Wu, J.J. (Eds.), The Oxford Handbook of Land Economics. Oxford University Press, New York, NY.

Lindenmayer, D.B., 2017. Conserving large old trees as small natural features. Biol. Conserv. this issue.

Lundquist, C.J., Bulmer, R.H., Clark, M.R., Hillman, J., Nelson, W.A., Norrie, C.R., Rowden, A.A., Tracey, D.M., Hewitt, J.E., 2017. Small natural features: their role and importance in marine seascapes. Biol. Conserv. this issue.

Medellin, R.A., Wiederholt, R., Lopez-Hoffman, L., 2017. Bat caves as reservoirs of biodiversity and providers of ecosystem services. Biol. Conserv. this issue. 
Michael, D.R., Lindenmayer, D.B., Cunningham, R.B., 2010. Managing rock outcrops to improve biodiversity conservation in Australian agricultural landscapes. Ecol. Manag. Restor. 11, 43-50.

Moncrieff, D., 2000. Managing tourism and recreation on Wheatbelt granite outcrops. J. R. Soc. West. Aust. 83, 187-196.

Naidoo, R., Balmford, A., Ferraro, P.J., Polasky, S., Ricketts, T.H., Rouget, M., 2006. Integrating economic costs into conservation planning. Trends Ecol. Evol. 21, 681-687.

Ostrom, E., Dietz, T., Dolsak, N., Stern, P.C., Stonich, S., Weber, E.U. (Eds.), 2002. The Drama of the Commons. National Academies Press.

Pasquini, L., Cowling, R.M., Twyman, C., Wainwright, J., 2010. Devising appropriate policies and instruments in support of private conservation areas: lessons learned from the Klein Karoo, South Africa. Conserv. Biol. 24, 470-478.

Pattanayak, S.K., Wunder, S., Ferraro, P.J., 2010. Show me the money: do payments supply environmental services in developing countries? Rev. Environ. Econ. Policy 4 (2), 254-274.

Perkins, A.J., Maggs, H.E., Watson, A., Wilson, J.D., 2011. Adaptive management and targeting of agri-environment schemes does benefit biodiversity: a case study of the corn bunting Emberiza calandra. J. Appl. Ecol. 48, 514-522.

Pettorelli, N., Safi,K., Turner,W., 2014. Satellite remote sensing, biodiversity research and conservation of the future. Philos. Trans. R. Soc. Lond. B Biol. Sci. 369, 20130190.

Polasky, S., Doremus, H., 1998. When the truth hurts: endangered species policy on private land with imperfect information. J. Environ. Econ. Manag. 35, 22-47.

Polasky, S., Lewis, D.J., Plantinga, A.J., Nelson, E., 2014. Implementing the optimal provision of ecosystem services. Proc. Natl. Acad. Sci. 111, 6248-6253.

Poschlod, P., Braun-Richert, 2017. Small natural features with large ecological roles in ancient anthropogenic landscapes: a review of their history, value, and conservation in Central Europe. Biol. Conserv. this issue.

Rissman, A.R., Lozier, L., Comendant, T., Kareiva, P., Kiesecker, J.M., Shaw, M.R., Merenlender, A.M., 2007. Conservation easements: biodiversity protection and private use. Conserv. Biol. 21, 709-718.

Robertson, G.P., Gross, K.L., Hamilton, S.K., Landis, D.A., Schmidt, T.M., Snapp, S.S., Swinton, S.M., 2014. Farming for ecosystem services: an ecological approach to production agriculture. Bioscience 64, 404-415. 
Rosenberg, S., Margerum, R.D., 2008. Landowner motivations for watershed restoration: lessons from five watersheds. J. Environ. Plan. Manag. 51, 477-496.

Rossi, A.M., Webb, R.E., 2007. The consequences of allowing unrestricted tourist access at an aboriginal site in a fragile environment: the erosive effect of trampling. Conserv. Manag. Archeol. Sites 9, 219-236.

Ruckelshaus, M., McKenzie, E., Tallis, H., Guerry, A., Daily, G., Kareiva, P., Polasky, S., Ricketts, T., Bhagabati, N., Wood, S.A., Bernhardt, J., 2015. Notes from the field: lessons learned from using ecosystem service approaches to inform real-world decisions. Ecol. Econ. 115, 11-21.

Ryan, R.L., Erickson, D.L., Young, R.D., 2003. Farmers' motivations for adopting conservation practices along riparian zones in a mid-western agricultural watershed. J. Environ. Plan. Manag. 46, 19-37.

Saunders, C.D., Brook, A.T., Myers, O.E., 2006. Using psychology to save biodiversity and human well-being. Conserv. Biol. 20 (3), 702-705.

Schlüter, M., Baeza, A., Dressler, G., Frank, K., Groeneveld, J., Jager, W., Janssen, M.A., McAllister, R.R.J., Müller, B., Orach, K., Schwarz, N., Wijermans, N., 2017. Aframework for mapping and comparing behavioral theories in models of social-ecological systems. Ecol. Econ. 131, 21-35.

Schultz, P., 2011. Conservation means behavior. Conserv. Biol. 25 (6), 1080-1083.

Sorice, M.G., Haider, W., Conner, J.R., Ditton, R.B., 2011. Incentive structure of and private landowner participation in an endangered species conservation program. Conserv. Biol. 25, 587-596.

Sorice, M.G., Conner, J.R., Kreuter, U.P., Wilkins, R.N., 2012. Centrality of the ranching lifestyle and attitudes toward a voluntary incentive program to protect endangered species. Rangel. Ecol. Manag. 65, 144-152.

Sterner, T., Coria, J., 2013. Policy Instruments for Environmental and Natural Resource Management. Routledge.

Stoneham, G., Chaudhri, V., Ha, A., Strappazzon, L., 2003. Auctions for conservation contracts: an empirical examination of Victoria's BushTender trial. Aust. J. Agric. Resour. Econ. 47, 477-500.

Tapsuwan, S., Burton, M., Perriam, J., 2010. A multivariate probit analysis of willingness to pay for cave conservation: a case study of Yanchep National Park, Western Australia. Tour. Econ. 16, 1019-1035. 
Thorgersen, J., 1996. Recycling and morality: a critical review of the literature. Environ. Behav. 28 (4), 536-558.

Trenholm, R., Lantz, V., Martínez-Espiñeira, R., Little, S., 2013. Cost-benefit analysis of riparian protection in an eastern Canadian watershed. J. Environ. Manag. 116, 81-94.

Trujillo, J.C., Carrillo, B., Charris, C.A., Velilla, R.A., 2016. Coral reefs under threat in a Caribbean marine protected area: assessing divers' willingness to pay toward conservation. Mar. Policy 68, 146-154.

van Beynen, P.E. (Ed.), 2011. Karst management. Springer Science \& Business Media.

Watson, K.B., Ricketts, T., Galford, G., Polasky, S., O'Niel-Dunne, J., 2016. Quantifying flood mitigation services: The economic value of Otter Creek wetlands and floodplains to Middlebury, VT. Ecol. Econ. 130, 16-24.

Wegner, G.I., 2016. Payments for ecosystem services (PES): a flexible, participatory, and integrated approach for improved conservation and equity outcomes. Environ. Dev. Sustain. 18, 617-644. 